\title{
PENGARUH KONSUMSI JANTUNG PISANG TERHADAP PENINGKATAN PRODUKSI ASI PADA IBU MASA NIFAS
}

\author{
Harismayanti ${ }^{1}$, Rona Febriyona ${ }^{2}$, Merlin Tuna ${ }^{3}$ \\ Universitas Muhammadiyah Gorontalo \\ Email : harismayanti@umgo.ac.id
}

\begin{abstract}
Research method used Quasy Eksperimen Two Group Pretest and Posttest Design. The population is 83 respondents. Collecting samples used random sampling technique with 20 respondents which divided into 10 respondents of cases group and 10 respondents of control group. The research result used Wilcoxon Signed Ranks Test showed $p$ value $=0,003<0,005$, it means there is the influence of banana blossom consumption in increasing ASI production on postpartum mother. While in control group the result of Wilxocon Signed Ranks Test showed p value $=0,317$ $>0,005$, thus there is no significance influence in control group. It's concluded that banana blossom has the significance influence in ASI production.
\end{abstract}

Keywords : Banana Blossom; ASI Production

\section{PENDAHULUAN}

ASI ekslusif merupakan pemberian ASI (Air Susu Ibu) secara ekslusif selama 6 bulan tanpa diberi makanan lain kecuali vitamin, mineral dan obat dalam bentuk oralit, tetes dan sirup. WHO merekomendasikan pemberian ASI selama 6 bulan dan dilanjutkan pemberian ASI sampai dua tahun pertama kehidupan. ASI memiliki keseimbangan zat-zat gizi yang tepat dalam bentuk mudah di cerna dan biovailble, serta meningkatkan sistem kekebalan dan menurunkan resiko ISPA pada bayi. ASI adalah satu-satunya makanan dan minuman terbaik untuk bayi. Komposisinya sesuai untuk pertumbuhan dan perkembangan bayi (Mustika, 2016).

Dukungan pemberian ASI ini sangat dibutuhkan karena cakupan pemberian ASI yang masih rendah. Menurut UNICEF, cakupan rata-rata ASI eksklusif di dunia yaitu 38\%. Menurut WHO, cakupan ASI Eksklusif di beberapa Negara ASEAN juga masih cukup rendah antara lain India (46\%), Philipina (34\%), Vietnam (27\%), Myanmar (24\%), dan Indonesia (54,3\%) (Kemenkes, 2014).

Menurut Depkes (2015) capaian ASI eksklusif di Indonesia belum mencapai angka yang diharapkan yakni sebesar $80 \%$. Pada tahun 2012, capaian ASI eksklusif sebesar 42\%. Sedangkan pada tahun 2013, cakupan pemberian ASI eksklusif sebesar 54,3\%.

Berdasarkan data dari Dinas Kesehatan Kabupaten Gorontalo jumlah data ASI eksklusif pada tahun 2015 mencapai 54\%, pada tahun 2016 mengalami 
peningkatan menjadi 60,7\%, dan pada tahun 2017 terjadi lagi penurunan menjadi 31,1\%. Sedangkan data dari Puskesmas Global Boliyohuto jumlah ASI eksklusif mencapai 68,9\% pada tahun 2015, sedangkan pada tahun 2016 jumlah ASI eksklusif sebesar 31\%, dan pada tahun 2017 mencapai 33\%. Hal ini membuktikan adanya penurunan jumlah ASI eksklusif dari tahun ke tahun.

Masalah yang ditimbulkan dari ibu menyusui adalah tidak maksimalnya produksi ASI, sehingga kebutuhan nutrisi bayi ikut tidak maksimal. Beberapa saran yang perlu diperhatikan para ibu yang sedang memberikan ASI pada bayi, yaitu mengkonsumsi sayur-sayuran dan buah-buahan yang dapat meningkatkan volume ASI. Jumlah ASI sedikit bisa diatasi ibu dengan mengkonsumsi daun pepaya, kacang panjang dan jantung pisang (Tjahjani, 2014).

Jantung pisang merupakan jenis tanaman yang mengandung laktagogum memiliki potensi dalam menstimulasi hormon oksitosin dan prolaktin seperti alkaloid, polifenol, steroid, flavonoid dan substansi lainnya paling efektif dalam meningkatkan dan memperlancar produksi ASI. Reflek prolaktin secara hormonal untuk memproduksi ASI, sewaktu bayi menghisap putting payudara ibu, maka akan terjadi rangsangan neurohormonal pada putting susu dan areola ibu. Rangsangan ini akan diteruskan ke hipofisis melalui nervos vagus, kemudian ke lobus anterio. Dari lobus ini akan mengeluarkan hormon prolaktin dan masuk ke peredaran darah dan sampai pada kelenjar-kelenjar pembuat ASI. Kelenjar ini akan terangsang untuk menghasilkan ASI (Wahyuni, 2012). Alasan ini sesuai dengan penelitian yang dilakukan oleh Elly Wahyuni pada tahun 2012 dengan judul penelitian pengaruh konsumsi jantung pisang batu terhadap peningkatan produksi ASI di Wilayah Puskesmas Srikuncoro Bengkulu Tengah. Dengan hasil penelitian diperoleh bahwa intesitas rata-rata frekuensi ASI sebelum konsumsi jantung pisang batu adalah 5,7 kali, setelah mengkonsumsi jantung pisang mengalami peningkatan menjadi 9,75 kali.

Salah satu makanan olahan tradisional dari tanaman pisang adalah bagian jantungnya. Karena hampir seluruh wilayah tanah air mengenal pohon pisang. Begitupun di Gorontalo, sayur jantung pisang di daerah Gorontalo dikenal dengan nama sayur putungo. Sayur putungo menjadi menu sederhana masyarakat Gorontalo dan menjadi ikon kuliner kota Gorontalo dimana terdapat cita rasa yang sangat pedas pada sayur ini. Sayur sederhana ini ternyata menjadi makanan utama di Gorontalo. Sayur putungo adalah masakan khas Gorontalo yang terbuat dari bahan dasar menggunakan jantung pisang, sayur putungo ini juga termasuk masakan tradisional. Jantung pisang ini diolah dengan berbagai macam cara, menyesuaikan menu yang disandingkan dengan sayur putungo atau jantung pisang ini. Dapat dibuat santan, tumis, atau sekedar lalapan biasa (Wijaya Ardy, 2017).

Penelitian ini bertujuan untuk mengetahui pengaruh konsumsi jantung pisang terhadap peningkatan produksi ASI pada ibu masa nifas. 


\section{METODE PENELITIAN}

Penelitian ini dilakukan di Wilayah Kerja Puskesmas Global Boliyohuto, Kecamatan Boliyohuto Kabupaten Gorontalo Provinsi Gorontalo. Jenis penelitian yang diguanakan dalam penelitian ini adalah jenis penelitian Quasy Eksperimen dengan rancangan Two Group Pretest and Postest Design.

Variabel Independen (bebas) pada penelitian ini adalah konsumsi jantung pisang dan variabel dependen (terikat) adalah produksi ASI. Populasi dalam penelitian ini ibu masa nifas yang menyusui diwilayah kerja Puskesmas Global Boliyohuto yang berjumlah 83 orang. Teknik yang digunakan dalam pengambilan sampel menggunakan teknink Random Sampling 24\% dari jumlah populasi dibagi menjadi 10 orang kelompok intervensi dan 10 orang kelompok kontrol. Pada Kelompok intervensi pemberian jantung pisang diberikan selama 1 minggu dengan frekuensi 2 kali sehari yang disajikan dalam bentuk sayur kuah bening dengan bahan jantung pisang sebanyak 200 gram.

\section{HASIL DAN PEMBAHASAN}

Tabel 1. Karateristik responden berdasarkan usia (kelompok intervensi dan kontrol)

\begin{tabular}{lcc}
\hline Usia & Frekuensi & $(\%)$ \\
\hline $17-25$ & 4 & $40,0 \%$ \\
$26-35$ & 4 & $40,0 \%$ \\
$36-45$ & 2 & $20,0 \%$ \\
\hline Total sampel intervensi & 10 & $100,0 \%$ \\
\hline $17-25$ & 5 & $50,0 \%$ \\
$26-35$ & 5 & $50,0 \%$ \\
\hline Total sampel kontrol & 10 & $100,0 \%$
\end{tabular}

Sumber data primer 2018

Berdasarkan tabel 1 diketahui bahwa responden terbanyak berada pada kelompok umur 17 - 15 tahun (40\%)

Tabel 2. Karakteristik responden berdasarkan pendidikan (kelompok intervensi dan kontrol)

\begin{tabular}{lcc}
\hline Pendidikan & Frekuensi & $(\%)$ \\
\hline Rendah & 3 & $30,0 \%$ \\
Menengah & 2 & $20,0 \%$ \\
Tinggi & 5 & $50,0 \%$ \\
\hline Total Sampel intervensi & 10 & $100,0 \%$ \\
\hline Rendah & 1 & $10,0 \%$ \\
Menegah & 2 & $20,0 \%$ \\
Tinggi & 7 & $70,0 \%$ \\
\hline
\end{tabular}



Total Sampel kontrol
10
$100,0 \%$

\section{Sumber data primer 2018}

Berdasarkan tabel 2 di ketahui responden berdasarkan tingkat pendidikan terbanyak pada tingkat pendidikan Tinggi (SMA/PT)

Tabel 3. Karakteristik responden berdasarkan pekerjaan (kelompok intervensi dan

\begin{tabular}{lcc}
\multicolumn{1}{c}{ kontrol) } & & \\
\hline Pekerjaan & Frekuensi & $(\%)$ \\
\hline Bekerja & 1 & $10,0 \%$ \\
Tidak Bekerja & 9 & $90,0 \%$ \\
\hline \multicolumn{1}{c}{ Total Sampel intervensi } & 10 & $100,0 \%$ \\
\hline Bekerja & 2 & $20,0 \%$ \\
Tidak Bekerja & 8 & $80,0 \%$ \\
\hline \multicolumn{1}{c}{ Total Sampel kontrol } & 10 & $100,0 \%$
\end{tabular}

Sumber data primer 2018

Berdasarkan tabel 3 di ketahui bahwa berdasarkan pekerjaan terbanyak yaitu tidak bekerja (90\%).

Tabel 4. Distribusi frekuensi produksi ASI pada ibu masa nifas sebelum dan sesudah konsumsi jantung pisang (kelompok intervensi)

\begin{tabular}{lll}
\hline Produksi ASI & Frekuensi & $(\%)$ \\
\hline Pretest & & \\
Tidak Lancar & 10 & $100,0 \%$ \\
Lancar & 0 & $0,0 \%$ \\
\hline Posttest & & \\
Tidak Lancar & 1 & $10,0 \%$ \\
Lancar & 9 & $90,0 \%$ \\
\hline
\end{tabular}

Sumber data primer 2018

Berdasarkan tabel 4 didapatkan hasil pretest 10 responden pengeluaran ASInya tidak lancar. Sedangkan setelah mengkonsumsi jantung pisang selama 1 minggu produksi ASI pada ibu nifas yang berjumlah 10 orang, 9 responden diantaranya produksi ASInya menjadi lancar, dan 1 responden tidak lancar.

Tabel 5. Distribusi frekuensi produksi ASI pada kelompok kontrol

\begin{tabular}{lll}
\hline Produksi ASI & Frekuensi & $(\%)$ \\
\hline Pretest & & \\
Tidak Lancar & 4 & $40,0 \%$ \\
Lancar & 6 & $60,0 \%$ \\
\hline Posttest & &
\end{tabular}




\begin{tabular}{lll} 
Tidak Lancar & 3 & $30,0 \%$ \\
Lancar & 7 & $70,0 \%$ \\
\hline
\end{tabular}

Sumber data primer 2018

Berdasarkan tabel 5 pada kelompok kontrol juga mengalami peningkatan produksi ASI namun tidak signifikan

Tabel 6. Hasil analisis pengaruh sebelum dan sesudah konsumsi jantung pisang terhadap peningkatan produksi ASI

\begin{tabular}{|c|c|c|c|c|c|}
\hline & & $\mathrm{N}$ & $\begin{array}{l}\text { Mean } \\
\text { Rank }\end{array}$ & & Sum of Rank \\
\hline \multirow{8}{*}{$\begin{array}{l}\text { Sesudah } \\
\text { Sebelum }\end{array}$} & Negat & $0^{\mathrm{a}}$ & .00 & .00 & \\
\hline & ive & & & & \\
\hline & Ranks & & & & 0,003 \\
\hline & Positi & $9^{b}$ & 5.00 & 45.00 & \\
\hline & ve & & & & \\
\hline & Ranks & & & & \\
\hline & Ties & $1^{\mathrm{c}}$ & & & \\
\hline & Total & 10 & & & \\
\hline \multirow{7}{*}{$\begin{array}{l}\text { Control } \\
\text { kontrol }\end{array}$} & Negat & $0^{\mathrm{d}}$ & .00 & .00 & \\
\hline & ive & & & & \\
\hline & Ranks & & & & 0,317 \\
\hline & $\begin{array}{l}\text { Positi } \\
\text { ve }\end{array}$ & $1^{\mathrm{e}}$ & 1.00 & 1.00 & \\
\hline & Ranks & & & & \\
\hline & Ties & $9^{f}$ & & & \\
\hline & Total & 10 & & & \\
\hline
\end{tabular}

Sumber data primer 2018

Berdasarkan tabel 6 terlihat bahwa pada kelompok intervensi pada Negative Ranks atau selisih (negatif) antara sebelum dan sesudah konsumsi jantung pisang adalah 0, baik pada nilai N, Mean Rank, maupun Sum of Rank. Nilai 0 ini menunjukkan tidak adanya penurunan (pengurangan) dari nilai sebelum dan sesudah konsumsi jantung pisang. Pada Positive Ranks atau selisih (positif) produksi ASI sebelum dan sesudah konsumsi jantung pisang terdapat 9 data positif yang artinya 9 responden mengalami peningkatan produksi ASI atau ASI menjadi lancar pada post test, Mean Ranks atau rata-rata peningkatan tersebut adalah 5,00 dan jumlah rangking positif atau Sum of Rank adalah 45,00. Sedangkan pada Ties atau kesamaan nilai pre test dan post test adalah 1 yang artinya 1 responden tetap memilki nilai yang sama pada pre test dan post test atau ASInya tidak mengalami peningkatan. Nilai $\mathrm{P}$ value 0,003 ada pengaruh konsumsi jantung jantung pisang dengan produksi ASI 
Hasil penelitian di Wilayah Kerja Puskesmas Global Boliyohuto diketahui bahwa pada kelompok intervensi dan kelompok kontrol yang memiliki usia 19-25 tahun berjumlah 9 responden, usia 26-35 tahun berjumlah 9 responden, dan yang berusia 36 sampai 45 berjumlah 2 responden.

Menurut Wawan dan Dewi 2010 usia adalah umur individu sejak dilahirkan. Semakin cukup umur tingkat kematangan dan kekuatan seseorang berfikir dan bekerja akan lebih baik. Sebagian besar ibu yang gagal memberikan ASI eksklusif adalah dalam masa reproduksi yaitu $<20$ tahun, pada usia ini seharusnya ibu telah memiliki kemampuan mental yang diperlukan untuk mempelajari dan menyesuaikan diri pada situasi-situasi yang baru seperti pemberian ASI eksklusif.

Hasil penelitian di Wilayah Kerja Puskesmas Global Boliyohuto diketahui bahwa pada kelompok intervensi dan kelompok kontrol yang berpendidikan rendah berjumlah 4 responden, menengah 4 responden, dan tinggi berjumlah 12 responden.

Semakin tinggi pendidikan ibu semakin muda menerima informasi yang disampaikan oleh tenaga kesehatan atau orang lain maupun dari media masa sehingga semakin tinggi pendidikan seseorang semakin matang dan lebih jauh untuk berfikir sesuatu yang baik buat dirinya dan akan berdampak pada kondisi psikologis dirinya yang lebih baik dalam menyiapkan kematangan dalam proses berfikir kedepannya (Kamariyah N, 2014).

Hasil penelitian di Wilayah Kerja Puskesmas Global Boliyohuto diketahui bahwa pada kelompok intervensi dan kelompok kontrol yang bekerja berjumlah 3 responden dan yang tidak bekerja berjumlah 17 responden.

Menurut Hardiani (2017) mengatakan bahwa pekerjaan ibu berpengaruh terhadap pemberian ASI eksklusif. Dari hasil penelitian rata-rata responden berprofesi sebagai ibu rumah tangga sebanyak 16 responden, PNS 4 responden, dan yang tidak bekerja 1 responden. Tugas seorang ibu rumah tangga sangat banyak diantaranya memasak, mencuci, mengurus anak dan suami. Hal ini mengakibatkan kelelahan atau letih pada ibu yang memicu penurunan produksi ASI. Ibu yang mengalami stres maka akan terjadi blokade dari refleks letdown. Hal ini disebabkan karena adanya pelepasan dari adrenalin (epinefrin) yang menyebabkan vasokontriksi pembuluh darah alveoli sehingga akan menghambat oksitosin untuk dapat mencapai target organ mioepitelium.

Dari hasil uji statistik Wilcoxon Signed Ranks Test pada kelompok intervensi didapatkan hasil $\mathrm{P}$ value 0,003 artinya ada pengaruh konsumsi jantung pisang terhadap peningkatan produksi ASI pada ibu masa nifas di Wilayah Kerja Puskesmas Global Boliyohuto. Pada post test 1 responden yang diberikan jantung pisang ASInya tetap tidak lancar karena pada hari kelima beliau tidak bersedia lagi mengkonsumsi jantung pisang dan juga ada faktor lain yang menghambat produksi ASI beliau menjadi tidak lancar seperti ketenangan jiwa dan fikirannya terganggu dan keadaan psikologis yang tertekan, sedih dan tegang. 
Sedangkan pada kelompok kontrol yang tidak diberikan perlakuan dari hasil uji statistik Wilcoxon Signed Ranks Test didapakan nilai P value 0,317 atau > 0,005 sehingga Ha ditolak yang artinya tidak ada pengaruh yang terjadi terhadap produksi ASI pada ibu masa nifas di Wilayah Kerja Puskesmas Global Boliyohuto. Karena pada kelompok ini tidak diberikan perlakuan untuk mengkonsumsi jantung pisang sehingga tidak terjadi peningkatan produksi ASI yang lancar terhadap ibu nifas pada kelompok kontrol. Setelah dilakukan post test hasilnya mengalami sedikit kenaikan karena 1 responden memiliki ASI yang tidak lancar sebelumnnya menjadi lancar, karena mengkonsumsi makanan lain selain jantung pisang.

ASI pada ibu nifas disebut lancar jika frekuensi menyusui bayi 8-10 kali perhari atau dalam 24 jam, bayi tidak rewel, frekuensi BAB 3-4 kali perhari, BAK 6 kali perhari, ASI merembes keluar melalui putting. Secara teoritis banyak faktor yang berpengaruh terhadap kelancaran ASI, baik faktor ibu maupun faktor luar ibu. Sekresi ASI diatur oleh hormon prolaktin dan oksitosin. Prolaktin menghasilkan ASI dalam alveolar dan bekerjanya prolaktin ini dipengaruhi oleh lama dan frekuensi pengisapan (suckling). Faktor lain yang mempengaruhi adalah frekuensi penyusuan, berat lahir, umur kehamilan, umur dan parites, stres dan penyakit akut, kebiasaan merokok, konsumsi alkohol, dan pil kontrasepsi (Sulistyawati, 2009).

Menurut Mohanis (2014) mengatakan bahwa memberikan ASI eksklusif kepada bayi sangat menguntungkan untuk tumbuh kembang bayi. Prilaku ibi-ibu memberikan ASI eksklusif pada bayinya dipengaruhi oleh beberapa faktor diantaranya faktor pengetahuan, pendidikan, sikap, pekerjaan, ketersediaan waktu, dorongan keluarga, dan faktor dari petugas kesehatan.

Proses produksi ASI juga dipengaruhi beberapa faktor diantaranya ialah faktor nutrisi, perawatan payudara, faktor isapan bayi, faktor sosial dan budaya, faktor mennyusui dan psikologis. Faktor nutrisi ini perlu diperhatikan oleh seorang ibu dalam proses menyusui karena dalam meningkatkan produksi ASI seorang ibu harus meningkatkan kebutuhan nutrisinya dengan cara meningkatkan porsi makan yang mengandung protein karena kandungan protein berfungsi untuk membentuk jaringan baru guna dalam produksi ASI (Kamariyah N, 2014).

Ibu nifas yang menyusui harus memperhatikan beberapa hal untuk bisa meningkatkan kualitas dan jumlah volume ASI yang dimilikinya. Ada beberapa saran yang perlu diperhatikan para ibu yang sedang memberikan ASI pada bayi, yakni mengkonsumsi sayur-sayuran dan buah-buahan yang dapat meningkatkan volume ASI. Jumlah ASI sedikit bisa diatasi dengan mengkonsumsi sayur katuk, labu siam, kacang pancang, dan jantung pisang. Kandungan kimia yang terkandung pada jantung pisang seperti kalori, protein, lemak, karbohidrat, vitamin A, vitamin $\mathrm{B} 1$, vitamin $\mathrm{C}$ dan mineral penting seperti fosfor, kalsium dan Fe (zat besi) akan sangat membantu dalam proses pembuatan ASI (Kappara, 2014).

Jantung pisang memiliki khasiat yang sangat baik bagi kesehatan, kandungan zat gizi yang bermanfaat bagi tubu ialah protein $12,05 \%$, karbohidrat 
$34,83 \%$, dan lemak total 13,05\%, mineral (terutama fosfor, kalsium, dan besi), serta sejumlah vitamin A, B1 dan C. Komponen penting lainnya yang terdapat pada jantung pisang adalah serat pangan yang sangat bermanfaat bagi kesehatan (Fattah, 2016). Menurut Kusumaningtyas (2010) komposisi gizi jantung pisang per 100 gram adalah : energi $31 \mathrm{kkal}$, protein $1,26 \mathrm{~g}$, lemak $0,35 \mathrm{~g}$, karbohidrat 8,31 g, kalsium $6 \mathrm{mg}$, besi 0,4 mg, fosfor $50 \mathrm{mg}$, vitamin A 140 SI, vitamin B1 0,006 mg, vitamin C $9 \mathrm{mg}$.

Jantung pisang memiliki khasiat terhadap peningkatan sekresi air susu (laktogogum) mempunyai kandungan bahan aktif yang bekerja seperti prolactin releasing hormon $(\mathrm{PRH})$, mengandung bahan aktif senyawa steroid, mengandung bahan aktif yang berkhasiat seperti prolaktin dan mengandung bahan aktif yang berkhasiat seperti oksitosin (Saadatullah, 2009).

Secara teknis kelancaran ASI dipengaruhi oleh makanan, salah satunya adalah jantung pisang yang bermanfaat untuk meningkatkan produksi ASIpada ibu nifas karena jantung pisang mengandung laktogogum yang berfungsi untuk merangsang hormon oksitosin untk pengeluaran ASI. Hasil penelitian ini sesuai dengan penelitian Wahyuni (2012) dengan judul pengaruh konsumsi jantung pisang batu terhadap peningkatan produksi ASI di Wilayah Kerja Puskesmas Srikuncoro Kecamatan Pondok Kelapa Bengkulu Tengah. Dari hasil penelitian ini diperoleh bahwa sebelum konsumsi jantung pisang batu frekuensi ASI 5,7 kali, dan setelah mengkonsumsi mengalami peningkatan menjadi 9,75 kali dengan sig 0,000 $<0,005$. Penelitian kedua yakni oleh Apriza (2016) dengan judul pengaruh konsumsi rebusan jantung pisang terhadap eksresi ASI pada ibu menyusui di Desa Kuapan Wilayah Kerja Puskesmas Tambang. Dari hasil penelitian diperoleh bahwa rata-rata eksresi ASI sebelum konsumsi rebusan jantung pisang adalah $385 \mathrm{cc}$ dengan standar devisiasi 82,876 dan sesudah konsumsi rebusan jantung pisang adalah 720,000 cc dengan standar devisiasi 86,450 dengan nilai $\mathrm{P}$ value 0,001. Penelitian ketiga oleh Tjahjani (2014) dengan judul pengaruh konsumsi jantung pisang terhadap kelancaran ASI pada ibu nifas di Puskesmas Gundi Kota Surabaya. Dengan hasil penelitian didapatkan $20 \%$ pada ibu nifas yang pengeluaran ASI tidak lancar, 80\% ibu nifas pengeluaran ASI menjadi lancar, pada $\alpha=0,05$ diperoleh $p$ value $=0,001$.

\section{KESIMPULAN}

1. Kesimpulan

Ibu nifas yang menyusui di Wilayah Kerja Puskesmas Global Boliyohuto mengkonsumsi olahan jantung pisang dalam bentuk kuah bening dengan jumlah 200 gram yang diberikan selama satu minggu dan dikonsumsi dua kali sehari.

Produksi ASI pada ibu nifas yang menyusui sebelum konsumsi jantung pisang rata-rata $100 \%$ tidak lancar, setelah konsumsi jantung pisang produksi ASI 90\% menjadi meningkat dan lancar dan $10 \%$ produksi ASInya tetap tidak lancar. 
Terdapat pengaruh konsumsi jantung pisang terhadap peningkatan produksi ASI di Wilayah Kerja Puskesmas Global Boliyohuto.

2. Saran

Diharapkan dengan diberikannya konsumsi jantung pisang serta dijelaskan manfaat jantung pisang untuk produksi ASI, ibu nifas dapat mengkonsumsi jantung pisang pada saat menyusui sebagai salah satu upaya dalam meningkatkan produksi ASI untuk mendukung pemberian ASI ekslusif.

Diharapkan menjadi referensi ilmu tambahan untuk meningkatkan produksi ASI dapat dilakukan dengan mengkonsumsi jantung pisang. Dan untuk Puskesmas bisa dijadikan sebagai salah satu bahan untuk melakukan penyuluhan tentang makanan yang dapat memperlancar ASI guna mendukung ASI ekslusif.

\section{DAFTAR PUSTAKA}

Bahriyah F. (2017). Hubungan Pekerjaan Ibu Terhadap Pemberian ASI Eksklusif Pada bayi. Journal Endurance 2(2) June 2017 (113-118).

Depkes. (2015). ASI Eksklusif di Indonesia.

Dinas Kesehatan Kabupaten Gorontalo. (2017). Jumlah Cakupan ASI di Dinas Kesehatan Gorontalo.

Fattah. (2016). Pengaruh Penambahan Bagian dan Level Jantung Pisang Terhadap Kualitas Fisik Sosis Daging Sapi. Jurnal Ilmu

Pertanian. Volume 2 Nomor 2, Desember 2016. Hal : 95-110.

Hardiyani. (2017). Status Paritas dan Pekerjaan Ibu Terhadap Pengeluaran ASI Pada Ibu Menyusui 0-6 Bulan. Nurseline Journal, Vol. 2 No. 1 Mei 2017 pISSN 2540-7937 e-ISSN 2541-464X. Hal:44-51.

Kamariyah, N. (2014). Kondisi Psikologi Mempengaruhi Produksi ASI Ibu Menyusui di BPS Aski Pakis Sido Kumpul. Jurnal Ilmiah Kesehatan, Vol 7, No 12, Februari 2014, Hal 29-36.

Kappara. (2014). Sehat Dengan Herbal Warisan Nenek Moyang Penumpas Segala Penyakit. Media Ilmu Abadi.

Kemenkes. (2014). Cakupan Rata-rata ASI Eksklusif di Dunia. 
Kusumaningtyas. (2010). Pengolahan Limbah Jantung Pisang (Musa paradisiaca). Jurnal Penerapan Teknologi dan Pembelajaran. Vol 8, No 2.

Mohanis. (2014). Peran Petugas Kesehatan dan Status Pekerjaan Ibu Dengan Pemberian ASI Eksklusif. Jurnal Kesehatan Masyarakat. Hal : 40-45.

Mustika, I. (2016). Determinan Pemberian ASI eksklusif Pada Ibu Menyusui. Journal Of Health Science and Prevention, Vol. 1(1), April 2017 (ISSN 2549919)

Okawary, O. (2015). Hubungan Status Pekerjaan Ibu Dengan Pemberian ASI Eksklusif di Wilayah Kerja Puskesmas Seyegan Sleman Yogyakarta

Proverawati. (2010). Kapita Selekta ASI dan Menyusui. Yogyakarta : Nuha Medika

Puskesmas Global Boliyohuto. (2017). Data Cakupan Pemberian ASI eksklusif.

Saadatullah. (2009). Pemanfaatan Jantung Pisang Kepok (Musa Paradisiaca). Fakultas Perikanan dan Ilmu Kelautan UNDIP, Semarang.

Sulistyawati, A. (2009). Buku Ajar Asuhan Kebidanan Pada Ibu Nifas (Edisi Pertama). Yogyakarta : Andi Office. 